$U D C 681.2$

TECHNICAL SCIENCES AND TECHNOLOGIES

DOI: $10.25140 / 2411-5363-2019-3(17)-162-167$

\title{
Lubica Miková
}

\section{DESIGN AND STRESS ANALYSIS OF WHEEL MOBILE ROBOT}

Urgency of the research. In the context of design of new, improved devices or technical systems containing electronic elements, we are increasingly encountering the concepts like mechatronics, mechatronic systems, mechatronics system solving approach or just simply mechatronics. The impact of mechatronics is most noticeable in mobile mechatronic products, especially in the automotive industry, where mechatronic systems are increasingly being used.

Target setting. The design a wheeled chassis with improved ability to cross rugged terrain. Its indivitual parts are subject of simualtions and stress ananlysis, which confirmed the advantage of the chosen design and mobility of the chassis.

Actual scientific researches and issues analysis. Designing a robot for a specific purpose always involves several steps. Before considering the design of a robot, it is necessary to determine the environment in which it should operate. The problem of four or more wheeled chassis arises when the wheels are unsprung and the unevenness of the terrain surface causes loss of wheel contact with the terrain surface and thus loss of traction.

Uninvestigated parts of general matters defining. The question of the physical design of a mobile robot is uninvestigated, because it will be solved in future.

The research objective. The main aim was design and stress analysis of individual parts of the mobile wheeled robot with improved ability to pass through rugged terrain.

The statement of basic materials. The chassis is based on five modules which are connected between each other. Its steering ability against each other is determined by the upper connection cover. Two modules integrated between wheels are for storage, which can be used for battery sources or auxiliary control.

Conclusions. All construction parts of this mobile robot were designed in Solidworks software, taking into account the simplicity of the structure and its ease of manufacture. The mobile chassis was tested in various terains simulations, where all his movements and terrain adaptation were monitored. The mobile chassis structure was recalculated from the point of view of the mechanics theory.

Keywords: wheeled mobile robot; simulation model.

Fig.: 10. Table: 1. References: 11 .

Introduction. Designing a robot for a specific purpose always involves several steps. Before considering the design of a robot, it is necessary to determine the environment in which it should operate, be it the type of surface or the obstacles it may encounter when moving in that environment. Four or more wheeled chassis with differential steering are simple at first sight, but the problem arises when the wheels are unsprung and the unevenness of the terrain surface causes loss of wheel contact with the terrain surface and thus loss of traction. This problem is not the case with two- and three-wheel chassis, which are naturally stable even in rugged terrain in terms of keeping the wheels in contact with the terrain. It is important to use a system to keep the wheels on the terrain surface so that locomotion can be realized [1-9]. The aim of this article is to design a wheeled chassis with improved ability to cross rugged terrain. Its indivitual parts are subject of simualtions and stress ananlysis, which confirmed the advantage of the chosen design and mobility of the chassis.

Mobile wheeled robot with increased ability to cross a rugged terrain. The chassis is based on five modules which are connected between each other. Its steering ability against each other is determined by the upper connection cover. Two modules integrated between wheels are for storage, which can be used for battery sources or auxiliary control. These modules are also used as a strut, formed by spacers for already mentioned upper connection cover, on which the control unit and possible superstructure can by mounted. The design of individual modules and system of tilting bushings of motors connected to the wheels, was the main issue, when designing the construction of mobile robot.

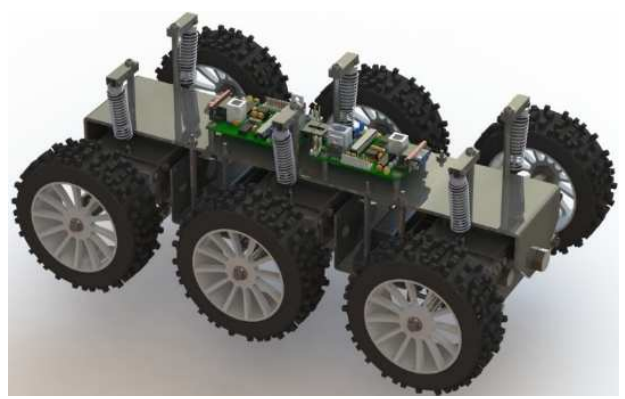

Fig. 1. Model of mobile robot

(с) Любица Микова, 2019 
TECHNICAL SCIENCES AND TECHNOLOGIES

As you can see on the Fig. 1, we proceed to design of the suspension of the individual modules on which the bushings are attached to the motors on the wheels by dashpots. They are attached to the top of the frame of the robot. The dashpots reduce rotation of the modules and absorb impacts caused by the wheel passing through the rugged terrain. Those vibrations may affect the electronic parts located on the upper body of the robot or any active superstructure sensitive to these vibrations. Rotation of individual modules is ensured by self-weight. When the wheel passes over and obstacle, the chassis is able to follow the terrain and thus increase the traction of the entire robot. Overall rotation of the modules is limited by mechanical stops, which limits this movement up to approximately 20 degrees. This range can be variable because it depends on the length of the holders of these stops. The rotation of the module is limited by the mechanical contact between the module and the connecting upper part itself.

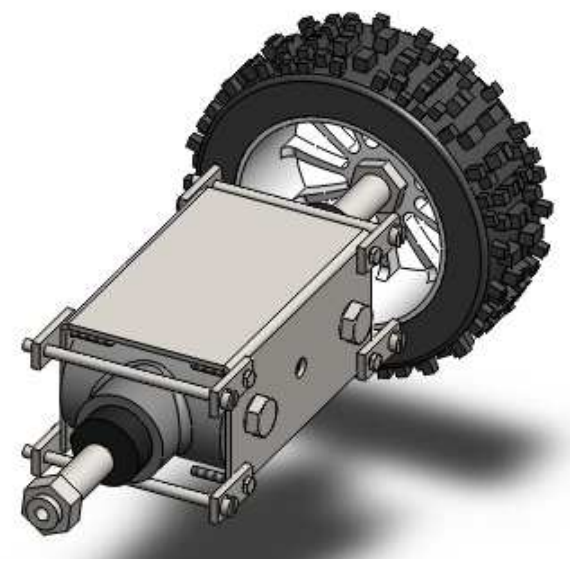

Fig. 2. Detail of mechanical limitation of the rotation for the bushings with motors

Upper body construction is from bent steel plate with $3 \mathrm{~mm}$ thicknes and chassis modules are from $2 \mathrm{~mm}$ steel plate. This should be sufficient for the stresses that occur when robot passes over an obstacle.
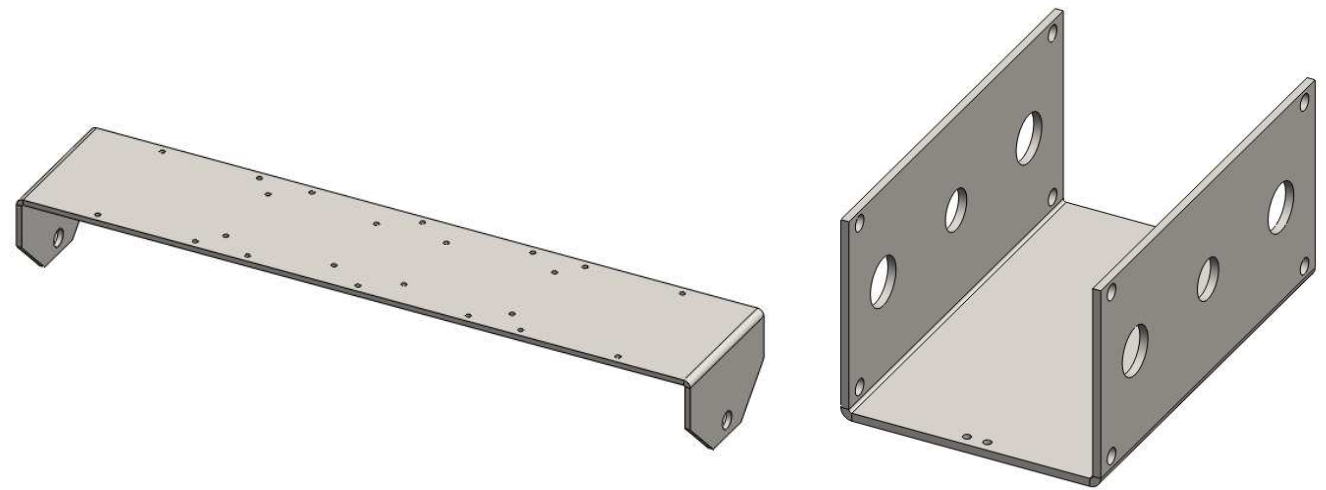

Fig. 3. Upper part of body construction and chassis module

Stress analysis of the supporting frame and individual parts of the chassis. Strength check of the supporting frame was done in SolidWorks software. The frame was loaded with a load capacity of $2 \mathrm{~kg}$ and three times its own weight, taking into account the dynamic stress. For allowed stress $\sigma_{D}$ following applies:

$$
\begin{gathered}
\sigma_{D}=\frac{R_{e}}{n} \\
\sigma_{D}=\frac{355}{2}=175,4 M P a
\end{gathered}
$$



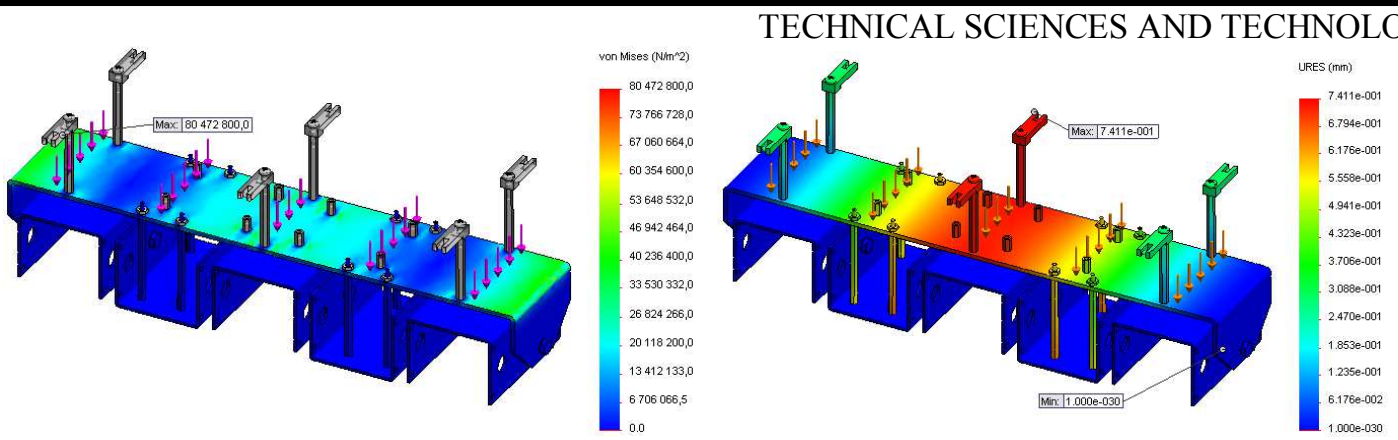

Fig. 4. Maximum stress and benning of the support frame

As can be seen on Fig. 4, the maximum stress reached approximately $80 \mathrm{MPa}$. Under this load the benning reached level of $0,74 \mathrm{~mm}$ in the center of the structure. This deformation does not affect functionality of the robot.

Individual chassis modules check when crossing obstacles. The designed mobile wheeled robot should be characterized by his improved ability to cross a rugged terrain, simulating the behavior of the designed construction solution in different environments and different situations.

Table

Parameters of simulation

\begin{tabular}{|c|c|}
\hline Estimated weight & $6 \mathrm{~kg}$ \\
\hline Estimated load capacity & $2 \mathrm{~kg}$ \\
\hline Engine speed & $40 \mathrm{rpm}$ \\
\hline $\begin{array}{c}\text { Static coefficient of friction fS } \\
\text { (coarse-grained asphalt) } \\
\text { (coarse-grained asphalt) }\end{array}$ & 1 \\
\hline $\begin{array}{c}\text { Dynamic coefficint of friction fS } \\
\text { Static coefficient of friction fS (concrete) }\end{array}$ & 1,25 \\
\hline Dynamic coefficient of friction fS (concrete) & 0,97 \\
\hline
\end{tabular}

For the purposes of the simulation, an obstacle track was created to simulate the rugged terrain with obstacles this chassis may encounter when moving in it. The track consisted of various protrusions, holes and at the end also obstacles for one row of wheels. Chassis behavior, suspension and tilting the bushes with motors was analyzed. During the simulation various strength analyses were evaluated for selected components, which were most heavily loaded during this test. During the movement, it was possible to observe the advantages of the proposed structure when crossing obstacles such as holes and surface irregularities. The rotation motor mounts followed the terrain, confirming the assumption of excellent robot traction. Also the advantage of tilting modules with dashpots was also confirmed, where the modules adjusted their position when passing one row of wheels over an obstacle and after returning from it they reestablished their starting position.

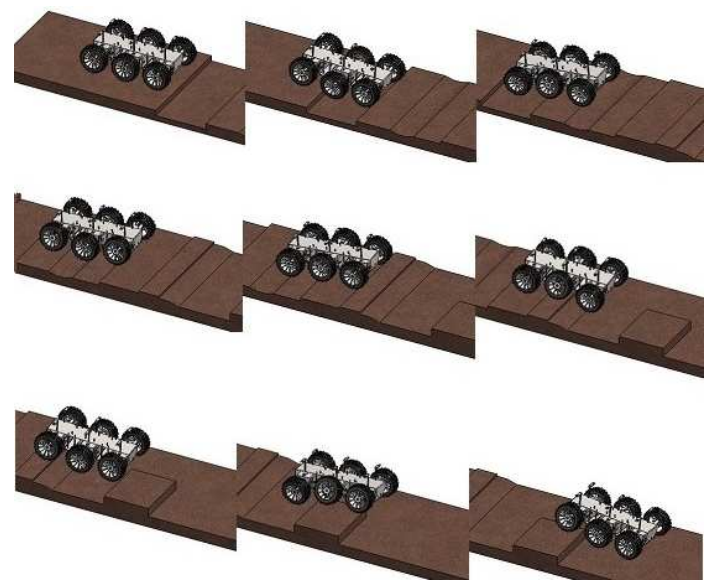

Fig. 5. Movement of mobile robot in terain 
TECHNICAL SCIENCES AND TECHNOLOGIES

Three critical points were selected where the stress reached maximum values. In Fig.6 it's possible to see the stress field during the crossing through uneven surface and obstacle at the end. Maximum value was reached when passing through uneven surface, aproximately 108 $\mathrm{MPa}$ at the point of the attachment the connecting screw. Possible solution of this problem was to apply a washer to the joint, to reduce this stress concentration.

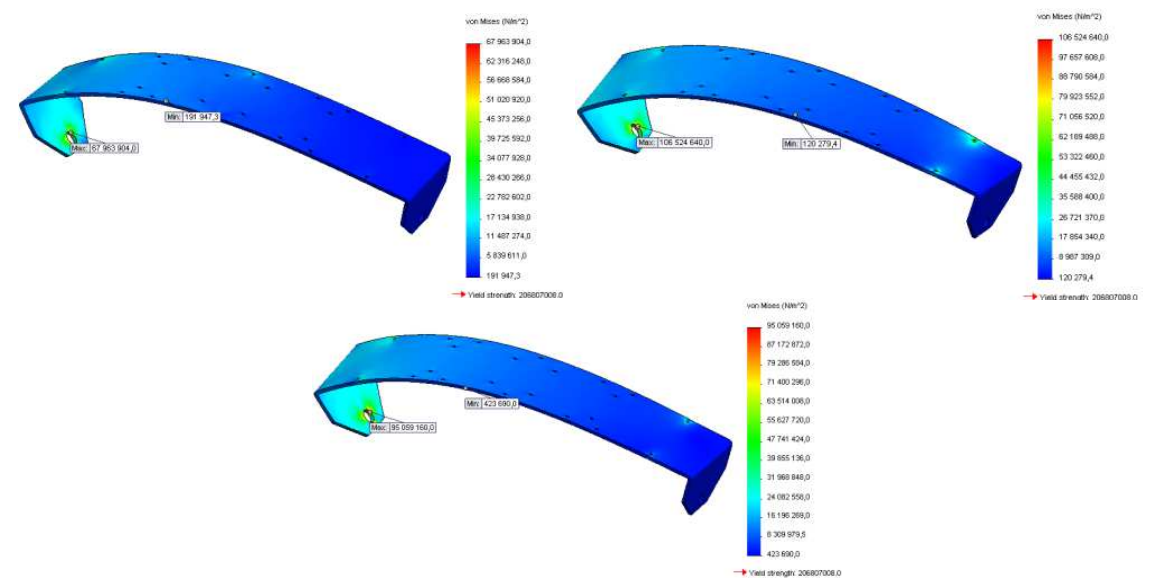

Fig. 6. Stress in upper body construction during the crossing the hole, uneven surface and last obstacle

The same case of loading occured on the chassis of the modules. The stress during the terain crossing reached $170 \mathrm{MPa}$ at the point where the module was connected to the body of the robot with screw. At this point the stress concentration had to be also limited. Therefore, a washer was mounted in the connection, which reduced the tension at this point to approximately $80 \mathrm{MPa}$.
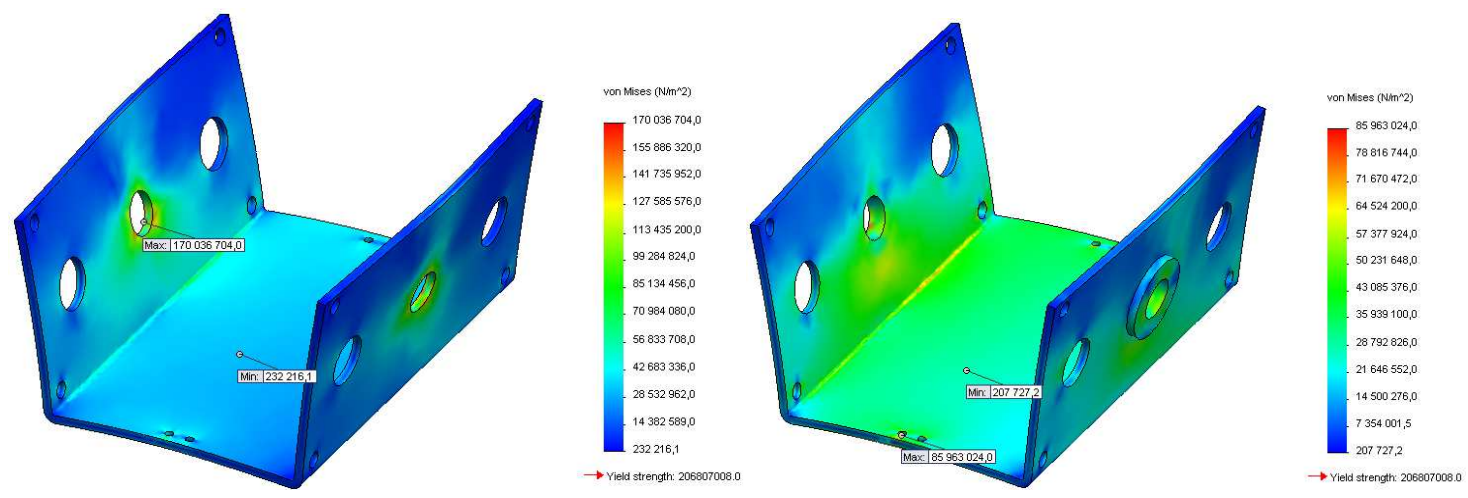

Fig. 7. Stress on the chassis module without the washer and with the washer

Another simulation was the movement of the mobile chassis down the stairs. One of the conditions of the design was the ability to move down the stairs without stuck in or tipping over. The stairs were constructed on the basis of building standards STN 734130 [7]. This standard discusses that the minimum width of a step shall be $250 \mathrm{~mm}$.

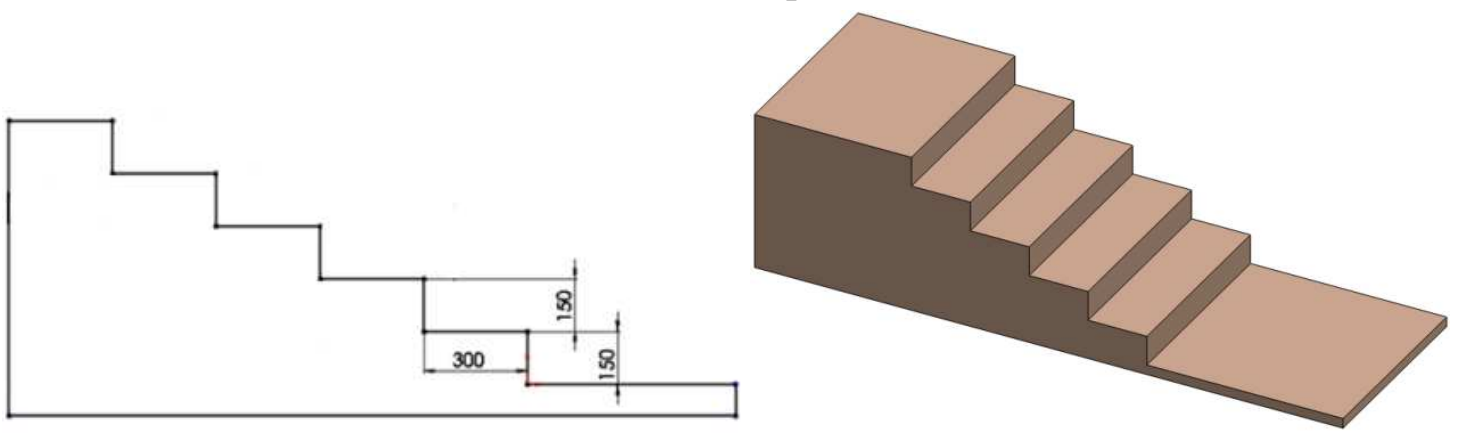

Fig. 8. Dimensions and staircase model 
TECHNICAL SCIENCES AND TECHNOLOGIES

As in previous simulations, the stresses and deformations of the construction were evaluated.

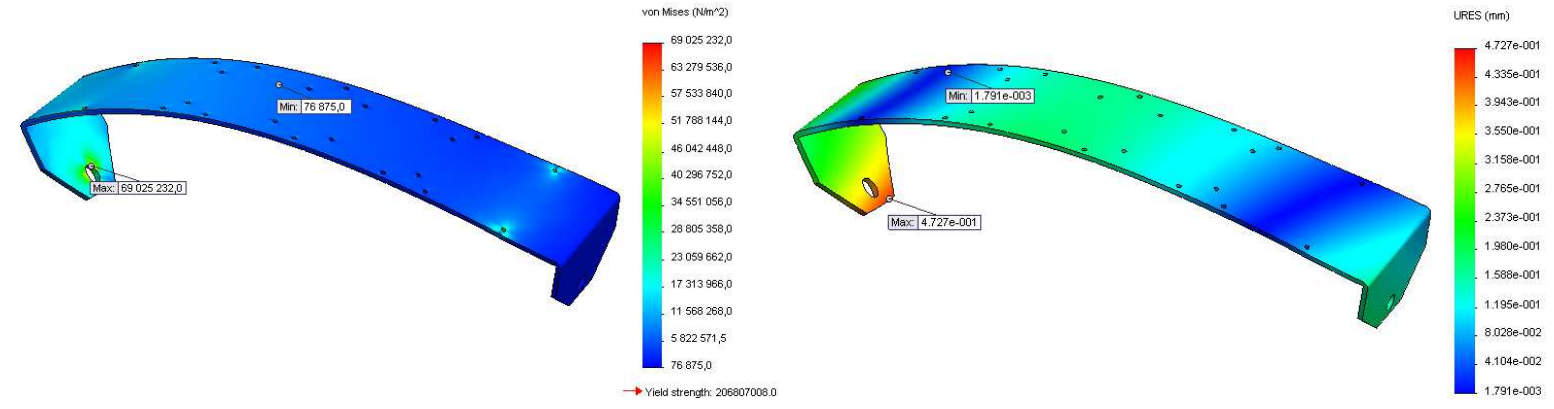

Fig. 9. Stress and deformation in upper chassis

In Fig. 9 the stress can be observed one the chassis module. When moving down the stairs, the maximum stress at the mounting point of the connecting screws was $150 \mathrm{MPa}$. Already in the previous case, washers had to be applied, which reduced the tension up to $60 \mathrm{MPa}$.
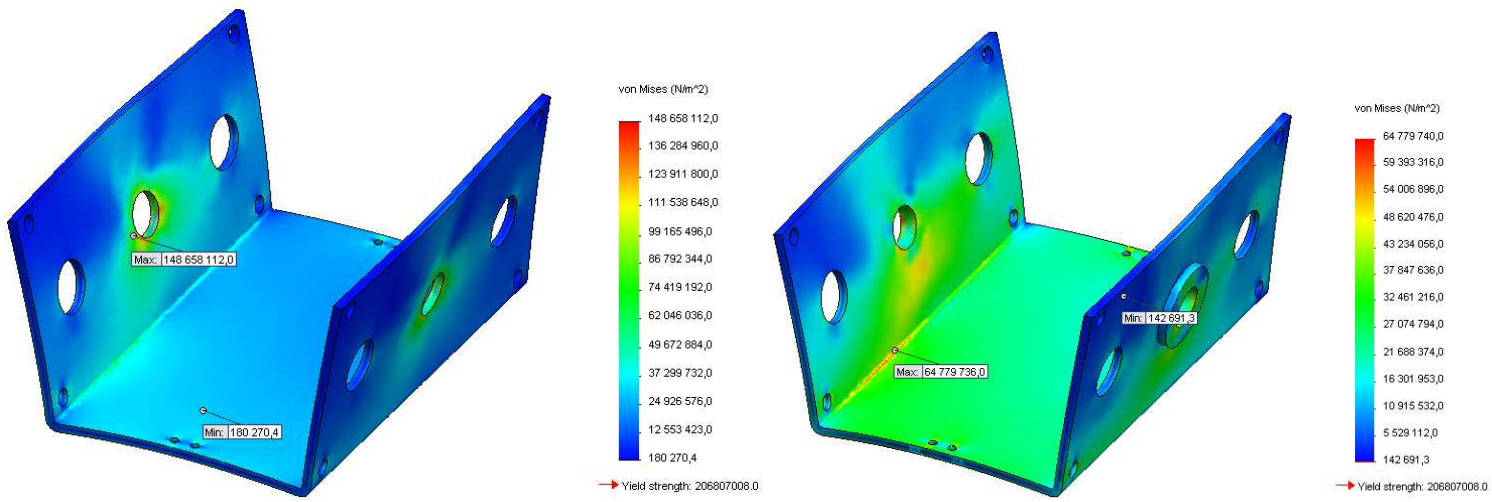

Fig. 10. Stress on the chassis module without the washer and with the washer

Conclusion. The aim of this article was design and stress analysis of individual parts of the mobile wheeled robot with improved ability to pass through rugged terrain. All construction parts of this mobile robot were designed in Solidworks software, taking into account the simplicity of the structure and its ease of manufacture. The mobile chassis was tested in various terains simulations, where all his movements and terrain adaptation were monitored. After evaluating the simulations and confirming his usefulness when passing through rugged terrain, the mobile chassis structure was recalculated from the point of view of the mechanics theory, so that the allowable stresses with respect to the yield point of the material were not exceeded.

Acknowledgement. This research was funded by Slovak Grant Agency VEGA1/0872/16 "Research of synthetic and biological inspired locomotion of mechatronic systems in rugged terrain" and by project Slovak Grant Agency VEGA 1/0389/18 "Research on kinematically redundant mechanisms".

\section{References}

1. Vitko, A., Jurišica, L., Babinec, A., Duchoň, F., \& Kl'účik, M. (2010) Some Didactic Problems of Teaching Robotics. Proceedings of the 1st International Conference Robotics in Education, Slovak University of Technology in Bratislava, ISBN 978-80-227-3353-3.

2. Kelemen, M., Kelemenová T., Jezný, J. (2008). Four legged robot with feedback control of legs motion. Bulletin of Applied Mechanics, 4 (16), 115-118.

3. Duchoň, F., Hubinský, P., Hanzel, J., Babinec, A., Tölgyessy, M. (2012). Intelligent Vehicles as the Robotic Applications. Procedia Engineering, 48.

4. Ivanjko, E., Komsic, I., Petrovic, C. (2007). Simple off-line odometry calibration of differential drive mobile robots. Proceedings of 16th International Workshop on Robotics in Alpe-Adria-Danube Region, Ljubljana, Slovenia, (pp. 164-169). 
TECHNICAL SCIENCES AND TECHNOLOGIES

5. Virgala, I., Vacková, M., Kelemen, M. (2010). Two-legs walking robot "Wirgil". Medical and treatment, 40 (2), (pp. 32-35).

6. Miková, L', Kelemen, M., Kelemenová, T. (2008). Four wheeled inspection robot with differential controlling of wheels. Acta Mechanica Slovaca, 12 (3-B), (pp. 548-558).

7. STN 734130 Schodištia a šikmé rampy - Základné ustanovenia.

8. Haiyang, J. Peng, Z., Ying, H., Jianwei, Z., Zhizeng, Z. (2010). Design and Kinematic Analysis of a Pedicle Screws Surgical Robot. Proceedings of the 2010 IEEE International Conference on Robotics and Biomimetics, Tianjin, China.

9. Koniar, D., Hargas, L., Simonova, E. (2014). Virtual Instrumentation for Visual Inspection in Mechatronic Applications. 6th Conference on Modelling of Mechanical and Mechatronic Systems (MMaMS), Slovakia.

10. Miková, L., Trebun̆a, F. (2012). The Application of Simulation Methods for Modeling Mechatronic Systems, Acta Mechanica Slovaca, Vol.. 16, No. 2, (pp. 32-36).

11. Gracia, L., Tornero, J. (2008). Kinematic control of wheeled mobile robots, Latin American Applied Research, Vol. 38, (pp. 7-16).

\section{УДК 681.2}

\section{Любица Микова \\ КОНСТРУКЦІЯ ТА СИЛОВИЙ АНАЛІЗ КОЛІСНОГО МОБІЛЬНОГО РОБОТА}

Актуальність теми дослідження. У контексті проектування нових, вдосконалених пристроїв або технічних систем, що містять електронні елементи, ми все частіше стикаємося з такими поняттями, як мехатроніка, мехатронні системи, підхід до вирішення систем мехатроніки або просто мехатроніка. Вплив мехатроніки найбільш помітний у мобільних мехатронних виробах, особливо в автомобільній промисловості, де все частіше застосовуються мехатронні системи.

Постановка проблеми. Конструювання колісного шасі з покращеною здатністю долати нерівну місцевість. Його окремі частини підлягають імітації силовим навантаженням, щэо підтвердило перевагу обраної конструкиї та мобільності шасі.

Аналіз останніх досліджень і публікацій. Проектування робота для конкретної мети завжди включає кілька етапів. Перш ніж розглянути конструкиію робота, необхідно визначити, в якому середовищі він повинен праџювати. Проблема чотирьох і більше колісних шасі виникає коли колеса не підресорені, а нерівність поверхні місцевості зумовлює втрату контакту колеса з нерівною поверхнею та відповідно втрату зчеплення.

Виділення недосліджених частин загальної проблеми. Питання про фізичну конструкцію мобільного робота не досліджено, оскільки це буде вирішено в майбутньому.

Постановка завдання. Основною метою було проектування та аналіз напружень окремих частин мобільного колісного робота з покращеною здатністю проходити через нерівну місчевість.

Виклад основного матеріалу. Шасі базується на п'яти модулях, які з'єднані між собою. Його керованість залежсть від модулів розташованих один проти одного і обмежується верхньою кришкою з'єднання. Два модуля, вбудовані між колесами, призначені для зберігання, які можна використовувати для джерел жсивлення або допоміжного управління.

Висновки відповідно до статті. Всі конструктивні частини изього мобільного робота були розроблені в програмному забезпеченні Solidworks з урахуванням простоти конструкиії та простоти виготовлення. Пересувне шасі тестувалося в різних моделях місиевості, де відслідковувалися всі його рухи та адаптаиія на місиевості. Пересувна структура шасі була перерахована з точки зору теоретичної механіки.

Ключові слова: колісний мобільний робот; імітаційна модель.

Рис.: 10. Табл.: 1. Бібл.: 11.

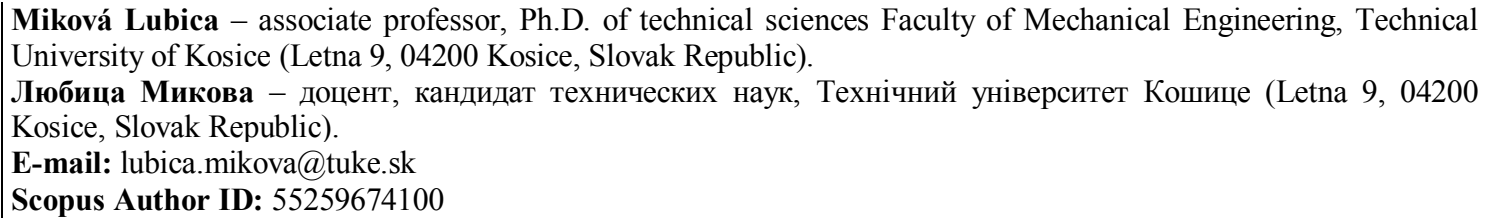

